\title{
INFLUENCE OF NITROGEN DOSE AND APPLICATION METHOD ON GROWTH AND YIELD OF BABY CORN
}

\author{
P.K. Biswas, N.J. Sarna and S. Shome \\ Department of Agronomy, Sher-e-Bangla Agricultural University, Dhaka-1207 \\ Corresponding E-mail: parimalbiswas @ hotmail.com
}

(Received: 18 September 2021, Received: 25 October 2021)

Keywords: Nitrogen management, cob yield, baby corn

\begin{abstract}
The experiment was conducted at Sher-e-Bangla Agricultural University during Rabi season of 2019-20 to find out the influence of nitrogen management on cob yield of baby corn. The experiment was laid out in a Split-plot design having 3 replications where four nitrogen dose viz., i) $0 \mathrm{~kg} \mathrm{~N}^{-1}\left(\mathrm{~N}_{1}\right)$, ii) $100 \mathrm{~kg} \mathrm{~N} \mathrm{ha}^{-1}\left(\mathrm{~N}_{2}\right)$, iii) $150 \mathrm{~kg} \mathrm{~N}^{-1}\left(\mathrm{~N}_{3}\right)$ and ii) $200 \mathrm{~kg} \mathrm{~N} \mathrm{ha}^{-1}\left(\mathrm{~N}_{4}\right)$ in the main plot and three nitrogenous fertilizer application method viz., i) Basal $\left(\mathrm{M}_{1}\right)$, ii) side dressing at 30 DAS $\left(\mathrm{M}_{2}\right)$ and iii) $50 \%$ basal $+50 \%$ side dressing at 30 DAS $\left(\mathrm{M}_{3}\right)$ in the sub-plot. Almost all the studied parameters were found statistically significant. The higher plant height, dry matter plant ${ }^{-1}$, number of cobs plant ${ }^{-1}$, fresh weight $\mathrm{cob}^{-1}$, husk weight $\mathrm{cob}^{-1}$ and cob yield were observed in application of 200 $\mathrm{kg} \mathrm{Nha}^{-1}$. Basal application of nitrogen fertilizer gave the highest cob weight and husk weight. Basal application of $200 \mathrm{~kg} \mathrm{~N} \mathrm{ha}^{-1}$ showed the highest plant height $(177.80 \mathrm{~cm})$, cobs plant ${ }^{-1}(2.91)$, cob length $(9.94 \mathrm{~cm})$, fresh cob weight $(61.05 \mathrm{~g})$, de-husked cob weight $(11.74 \mathrm{~g})$ and husk fresh weight $(49.30 \mathrm{~g})$ but the highest number of cobs ha ${ }^{-1}$ (218497) from $\mathrm{N}_{2} \mathrm{M}_{3}\left(100 \mathrm{~kg} \mathrm{Nha}^{-1}\right.$ applied $50 \%$ as basal dose and $50 \%$ at $\left.30 \mathrm{DAS}\right)$ and highest cob yield (7732.41 $\mathrm{kg} \mathrm{ha}^{-1}$ ) from $\mathrm{N}_{4} \mathrm{M}_{2}$ (application of $200 \mathrm{~kg} \mathrm{Nha}^{-1}$ at 30 DAS).
\end{abstract}

\section{Introduction}

Baby corn refers to the whole, entirely edible cobs of immature corn harvested just before fertilization at 2-3 cm long silk emergence stage. It is emerging worldwide as one of the high value crops due to its high nutritive value, delicious taste and very large demand by the foreign tourists. It is a low calorie vegetable having higher fibre content without cholesterol. No nutrients are utilized for seed set and hence, they are retained in plant part (stover) which make it nutritious cattle feed (Bakshi et al., 2016). Besides nutritive advantage, it is also freefrom residual effect of pesticides as it is harvested within aweek of tassel emergence and the young cob is wrapped uptightly with husk and well protected from insects and pests. Baby corn has primeplace as a safe and quality vegetable. To sustain the heavycattle population, baby corn can provide a valuablesupplementary source of green fodder (Bakshi and Wadhwa, 2012).

Baby corn is grown almost throughout the world is an off shoot of maize which is grown for its young, fresh, finger like green ears, harvested at the time of silk emergence and before pollination and fertilization (Ramchandrappa et al., 2004). Ears are ideal for baby corn if they are bite size, $5-10 \mathrm{~cm}$ long and $0.85-1.70 \mathrm{~cm}$ diameter at the base (Bar-Zur and Saadi, 1990). It contains 10.04g protein, $8.2 \mathrm{~g}$ carbohydrate, $0.20 \mathrm{~g}$ fat, $0.86 \mathrm{~g}$ phosphorus, $28 \mathrm{mg}$ calcium and $0.10 \mathrm{mg}$ iron per $100 \mathrm{~g}$ of edible portion (Thakur et al., 2000). Its byproducts such as tassel, young husk silk and green stalk provide feed for cattle and aquaculture (Bindhani et al., 2007). Moreover stover, dry leaves and cob covering can be used as good fuel (Ahmed, 1994 The soil and climate of our country is suitable for baby corn production. At present baby corn is growing in some areas of Chittagong hill tracts. The baby corn yield of Bangladesh is $0.99-1.1$ ton per hectare but its potentiality is 5 ton per hectare (BARI, 2004). 
So to meet the demand of baby corn it is imported from foreign countries like Thailand, Taiwan etc. and costing about Tk. 10 crore per year (BARI, 2004). The yield potential of baby corn is greatly influenced by proper method of nitrogen application with proper dose. An increased response to applied nitrogen was observed in baby corn by Pandey et al. (2002). Increased baby corn production can be achieved by changes of $\mathrm{N}$-fertilizer dose with appropriate application method. Optimum rate and time of $\mathrm{N}$ application can enhance yield productivity and nutrient use efficiencies while reducing the environmental pollution (Neilsen, 2013). The study was therefore, undertaken to find out the yield potentiality of baby corn with nitrogen fertilizer management.

\section{Materials and Methods}

The experiment was conducted at the Agronomy field of Sher-e-Bangla Agricultural University, Dhaka during the period from November 2019 to March 2020. The seeds of "Baby star" variety of baby corn was used as plant materials and the seeds were collected from Khustia seed store, Mirpur, Dhaka. The seeds were sown on 15 November, 2019 having a spacing of $45 \mathrm{~cm}$ x $20 \mathrm{~cm}$. The experiment was laid out in a Split-plot design with three replications where four nitrogen dose viz., i) $0 \mathrm{~kg} \mathrm{~N} \mathrm{ha}^{-1}\left(\mathrm{~N}_{1}\right)$, ii) $100 \mathrm{~kg} \mathrm{~N}^{-1}\left(\mathrm{~N}_{2}\right)$, iii) $150 \mathrm{~kg} \mathrm{~N}^{-1}\left(\mathrm{~N}_{3}\right)$ and ii) $200 \mathrm{~kg} \mathrm{~N}^{-1}\left(\mathrm{~N}_{4}\right)$ in the main- plot and three nitrogenous fertilizer application method viz., i) Basal $\left(\mathrm{M}_{1}\right)$, ii) $30 \mathrm{DAS}\left(\mathrm{M}_{2}\right)$ and iii) 50\% basal $+50 \%$ at 30 DAS $\left(\mathrm{M}_{3}\right)$ in the sub-plot. The chemical fertilizers i.e., urea as per treatment along with TSP and $\mathrm{MoP}$ as per recommended dose were used t. The whole amount of all fertilizers except urea was applied as a basla. Irrigation water was ensured to the field as and when necessary. Two hand weedings were done for all the treatments. The field was infested by different insects and diseases those controlled by applying appropriate ways in time.The immature cobs from harvest area of each plot werecollected and weighed atdifferent dates and finally converted as per hectare basis. Yield contributing and other relevant data like plant height at harvest, dry matter plant ${ }^{-1}$ at harvest, days to tasseling, days to silking, total number of cobs plant ${ }^{-1}$, cob length, cob diameter, fresh weight of cobs, dehusked cob yield plant ${ }^{-1}$, husk yield plant ${ }^{-1}$, number of harvested cobs $\mathrm{ha}^{-1}$ and fresh cob yield ha ${ }^{-1}$ were collected. Statistical analyses were done by using the Crop Stat computer package and the mean differences among the treatments were compared by least significant difference test at $5 \%$ level of significance.

\section{Results and Discussion}

\section{Plant height}

The plant height at harvest was significantly differed due to nitrogen dose and interactions of nitrogen dose and application method but insignificant for nitrogen application method (Table 1). The maximum t plant height $\left(176.33 \mathrm{~cm}\right.$ ) was found in $200 \mathrm{~kg} \mathrm{~N} \mathrm{ha}^{-1}$ that similar to 150 and $100 \mathrm{~kg} \mathrm{~N} \mathrm{ha}^{-1}$ whereas no nitrogenous fertilizer application showed the lowest plant height $(151.92 \mathrm{~cm})$ that also similar to 100 and $150 \mathrm{~kg} \mathrm{~N} \mathrm{ha}^{-1}$. The increment of plant height was 9.39, 15.40 and $16.07 \%$ in 100,150 and $200 \mathrm{~kg}$ $\mathrm{N}$ ha ${ }^{-1}$, respectively as compared to that of control (no nitrogen fertilizer) application. The present investigation corroborates the findings of Kar et al. (2006), Muniswamy et al. (2007), Suryavanshi et al. (2008) and Ashok Kumar (2009). Thakur et al. (1997) observed significant favourable effect of application of $150-200 \mathrm{~kg} \mathrm{~N} \mathrm{ha}^{-1}$ on plant height, functionalleaves plant ${ }^{-1}$, stem diameter, dry matter plant $^{-1}$, greenfodder yield, baby corn yield and net returns compared to the lower $\mathrm{N}$ levels. The maximum plant height was given by the combination $\mathrm{N}_{4} \mathrm{M}_{1}(177.80 \mathrm{~cm})$ that similar to all most all other interactions exceptthe lowest plant height $\left(149.33 \mathrm{~cm}\right.$ ) height in $\mathrm{N}_{1} \mathrm{M}_{1}$ that similar to $\mathrm{N}_{1} \mathrm{M}_{2}$ $(150.93 \mathrm{~cm}), \mathrm{N}_{1} \mathrm{M}_{3}(155.50 \mathrm{~cm})$ and $\mathrm{N}_{2} \mathrm{M}_{2}(162.07 \mathrm{~cm})$.

\section{Dry matter weight}


The maximum dry matter plant ${ }^{-1}(80.94 \mathrm{~g})$ at harvest was recorded in application of $200 \mathrm{~kg} \mathrm{~N}^{-1} \mathrm{ha}^{-1}$ that similar to $150 \mathrm{~kg} \mathrm{~N} \mathrm{ha}^{-1}(74.33 \mathrm{~g})$ and $150 \mathrm{~kg} \mathrm{~N} \mathrm{ha}^{-1}(70.86 \mathrm{~g})$ and the lowest dry matter plant ${ }^{-1}(58.97$ g) by no nitrogen application that similar to $\mathrm{N}_{2}$ and $\mathrm{N}_{3}$ (Table 1). Compared to that of no nitrogen application, the highest dry matter increment for nitrogen was found in $\mathrm{N}_{4}(37.26 \%)$ that followed by $\mathrm{N}_{2}(26.05 \%)$ and $\mathrm{N}_{3}(20.16 \%)$. The highest dry matter plant ${ }^{-1}(98.02 \mathrm{~g})$ was found in $\mathrm{N}_{3} \mathrm{M}_{3}$ (split application of $150 \mathrm{~kg} \mathrm{Nha}^{-1}$ ) that similar to almost all other interactions except $\mathrm{N}_{1} \mathrm{M}_{2}, \mathrm{~N}_{2} \mathrm{M}_{3}$ and $\mathrm{N}_{3} \mathrm{M}_{1}$. The lowest dry matter plant ${ }^{-1}(41.58 \mathrm{~g})$ was given by $\mathrm{N}_{1} \mathrm{M}_{2}$ that similar to almost all other interactions except $\mathrm{N}_{2} \mathrm{M}_{2}, \mathrm{~N}_{3} \mathrm{M}_{3}$ and $\mathrm{N}_{4} \mathrm{M}_{1}$.

\section{Days to tasseling and silking}

The tasseling and silking duration of baby corn was significantly varied for the interaction of nitrogen dose and application method (Table 1). The highest duration (79 days) was needed for $\mathrm{N}_{1} \mathrm{M}_{3}$ that similar to almost all other interactions except $\mathrm{N}_{2} \mathrm{M}_{1}, \mathrm{~N}_{2} \mathrm{M}_{3}, \mathrm{~N}_{3} \mathrm{M}_{1}, \mathrm{~N}_{3} \mathrm{M}_{3}$ and $\mathrm{N}_{4} \mathrm{M}_{3}$ whereas the lowest duration (75 days) was found in $\mathrm{N}_{2} \mathrm{M}_{1}$ that similar to almost all other interactions except $\mathrm{N}_{1} \mathrm{M}_{2}$, and $\mathrm{N}_{1} \mathrm{M}_{3}$. The highest silking duration (84 days) was found in $\mathrm{N}_{1} \mathrm{M}_{3}$ that similar to $\mathrm{N}_{2} \mathrm{M}_{2}$ (84 days), $\mathrm{N}_{1} \mathrm{M}_{1}$ (83 days) and $\mathrm{N}_{1} \mathrm{M}_{2}$ (83 days) whereas the lowest identical duration (81 days) was given by $\mathrm{N}_{2} \mathrm{M}_{1}$, $\mathrm{N}_{3} \mathrm{M}_{1}$ and $\mathrm{N}_{4} \mathrm{M}_{3}$ that similar to almost all other interactions except $\mathrm{N}_{1} \mathrm{M}_{1}, \mathrm{~N}_{1} \mathrm{M}_{2}, \mathrm{~N}_{1} \mathrm{M}_{3}$ and $\mathrm{N}_{2} \mathrm{M}_{2}$.

\section{Number of cobs plant ${ }^{-1}$}

There was significant variation observed among different nitrogen doses and interactions for number of cobs plant ${ }^{-1}$ and the maximum number of cobs plant ${ }^{-1}$ (2.50) was found in application of $200 \mathrm{~kg} \mathrm{Nha}^{-1}$ treatment that similar to $\mathrm{N}_{3}$ (2.37) and $\mathrm{N}_{2}$ (2.38) and the lowest number (2.11 plant ${ }^{-1}$ ) in control (Table 2). Higher number of cobs plant ${ }^{-1}$ (2.91) was found in $\mathrm{N}_{4} \mathrm{M}_{1}$ that similar to $\mathrm{N}_{2} \mathrm{M}_{3}$ (2.57) and $\mathrm{N}_{3} \mathrm{M}_{2}(2.55)$ and the lowest number of cobs plant ${ }^{-1}(1.91)$ by $\mathrm{N}_{1} \mathrm{M}_{1}$ that similar to $\mathrm{N}_{1} \mathrm{M}_{2}(2.15), \mathrm{N}_{3} \mathrm{M}_{1}(2.20), \mathrm{N}_{1} \mathrm{M}_{3}$ (2.26) and $\mathrm{N}_{2} \mathrm{M}_{2}$ (2.26). Irrespective of nitrogen application methods, the higher doses of nitrogen increased the number of cobs plant ${ }^{-1}$ that also supported by many researchers. Sahoo and Mahapatra (2004) reported that increase in the level of NPK increased the number of cobs plant ${ }^{-1}$, weight of whole green cob and yield of green cob significantly. Singh and Singh (1984) also observed more number of cobs in nitrogen fertilized plots of baby corn mainly due to reduction in per cent of barrenness rather than prolificacy.

\section{Cob length and cobdiameter}

There was no significant variation observed among different nitrogen dose and application method for cob length of baby corn though their interactions significantly varied where the highest cob length $(9.94 \mathrm{~cm})$ was found in $\mathrm{N}_{4} \mathrm{M}_{1}$ that similar to all other interactions except $\mathrm{N}_{1} \mathrm{M}_{1}(8.11 \mathrm{~cm})$ which showed the lowest cob length that also similar to all other interactions except $\mathrm{N}_{4} \mathrm{M}_{1}$ (Table 2). Cob girth did not show any variations for nitrogen dose, application method and their interactions.

Table 1. Growth parameters of baby corn as affected by nitrogen dose and application method

\begin{tabular}{lcccc}
\hline \multicolumn{1}{c}{ Treatments } & $\begin{array}{c}\text { Plant height } \\
(\mathbf{c m})\end{array}$ & $\begin{array}{c}\text { Dry matter } \\
\left(\mathbf{g ~ p l a n t}^{-\mathbf{1}}\right)\end{array}$ & $\begin{array}{c}\text { Days to } \\
\text { tasseling }\end{array}$ & $\begin{array}{c}\text { Days to } \\
\text { silking }\end{array}$ \\
\hline Nitrogen dose $(N)$ & & & & \\
$\mathrm{N}_{1}$ & 151.92 & 58.97 & 78 & 84 \\
$\mathrm{~N}_{2}$ & 166.18 & 74.33 & 76 & 82 \\
$\mathrm{~N}_{3}$ & 175.31 & 70.86 & 76 & 81 \\
$\mathrm{~N}_{4}$ & 176.33 & 80.94 & 76 & 81 \\
\hline $\mathrm{LSD}_{(0.05)}$ & 23.689 & 21.435 & $\mathrm{NS}$ & $\mathrm{NS}$ \\
\hline
\end{tabular}




\begin{tabular}{lcccc}
\hline $\begin{array}{l}\text { Nitrogen fertilizer application } \\
\text { method }(M)\end{array}$ & & & & \\
$\mathrm{M}_{1}$ & 167.45 & 71.02 & 76 & 82 \\
$\mathrm{M}_{2}$ & 166.62 & 68.15 & 77 & 82 \\
$\mathrm{M}_{3}$ & 168.24 & 74.66 & 76 & 82 \\
\hline $\mathrm{LSD}_{(0.05)}$ & $\mathrm{NS}$ & $\mathrm{NS}$ & $\mathrm{NS}$ & $\mathrm{NS}$ \\
\hline Interactions $(N x M)$ & & & & \\
$\mathrm{N}_{1} \mathrm{M}_{1}$ & 149.33 & 66.49 & 76 & 83 \\
$\mathrm{~N}_{1} \mathrm{M}_{2}$ & 150.93 & 41.58 & 78 & 83 \\
$\mathrm{~N}_{1} \mathrm{M}_{3}$ & 68.83 & 79 & 84. \\
$\mathrm{~N}_{2} \mathrm{M}_{1}$ & 155.50 & 81.18 & 75 & 81 \\
$\mathrm{~N}_{2} \mathrm{M}_{2}$ & 170.80 & 87.48 & 77 & 84 \\
$\mathrm{~N}_{2} \mathrm{M}_{3}$ & 162.07 & 54.32 & 75 & 81 \\
$\mathrm{~N}_{3} \mathrm{M}_{1}$ & 165.67 & 46.48 & 76 & 81 \\
$\mathrm{~N}_{3} \mathrm{M}_{2}$ & 171.87 & 68.07 & 76 & 82 \\
$\mathrm{~N}_{3} \mathrm{M}_{3}$ & 176.33 & 98.02 & 75 & 81 \\
$\mathrm{~N}_{4} \mathrm{M}_{1}$ & 177.73 & 89.91 & 77 & 82 \\
$\mathrm{~N}_{4} \mathrm{M}_{2}$ & 177.80 & 75.46 & 76 & 81 \\
$\mathrm{~N}_{4} \mathrm{M}_{3}$ & 177.13 & 77.45 & 76 & 81 \\
\hline $\mathrm{LSD}_{(0.05)}$ & 174.07 & 40.98 & 2.80 & 2.64 \\
\hline $\mathrm{CV}_{(\%)}$ & 14.46 & 33.22 & 2.12 & 1.86 \\
\hline
\end{tabular}

$\mathrm{N}_{1}=$ No nitrogen, $\mathrm{N}_{2}=100 \mathrm{~kg} \mathrm{Nha}^{-1}, \mathrm{~N}_{3}=150 \mathrm{~kg} \mathrm{Nha}^{-1}, \mathrm{~N}_{4}=200 \mathrm{~kg} \mathrm{Nha}^{-1}, \mathrm{M}_{1}=$ Basal, $\mathrm{M}_{2}=30$ DAS, M $=50 \%$ basal $+50 \%$ at $30 \mathrm{DAS}$

\section{Fresh weight $\operatorname{cob}^{-1}$}

Different nitrogen doses and interactions showed significant variation for cob fresh weight of baby corn. The maximum cob fresh weight $(41.29 \mathrm{~g})$ was found in application of $200 \mathrm{~kg} \mathrm{Nha}^{-1}$ treatment $\left(\mathrm{N}_{4}\right)$ that followedby $\mathrm{N}_{2}(38.93 \mathrm{~g})$ and $\mathrm{N}_{3}(38.01 \mathrm{~g})$ and the lowest cob fresh weight $(31.87 \mathrm{~g})$ in $\mathrm{N}_{1}$ (control) treatment (Table2). The fresh cob weight of $200 \mathrm{~kg} \mathrm{~N}^{-1}$ was $43.49 \%$ higher compared to that of cob weight in no nitrogen application. Higher doses of nitrogen gave higher cob yield of baby corn that also reported by Prathyusha and Hemalatha (2013).The interaction of nitrogen dose and application method resultedthe maximum cob fresh weight (47.71 g) in $\mathrm{N}_{4} \mathrm{M}_{1}$ that similar to $\mathrm{N}_{2} \mathrm{M}_{1}(42.90 \mathrm{~g}), \mathrm{N}_{4} \mathrm{M}_{2}(38.84 \mathrm{~g})$ and $\mathrm{N}_{2} \mathrm{M}_{2} \& \mathrm{~N}_{3} \mathrm{M}_{3}(38.56 \mathrm{~g})$ and the lowest cob fresh weight $(30.53 \mathrm{~g})$ in $\mathrm{N}_{1} \mathrm{M}_{1}$ that similar to $\mathrm{N}_{1} \mathrm{M}_{2}$ (32.02 g)and $\mathrm{N}_{1} \mathrm{M}_{3}$ (33.07 g). Similar higher cob fresh weight of baby corn with higher fertility level was also reported by Ghosh et al. (2017).

Table 2. Interaction effect of nitrogen dose and application method on crop characters of baby corn

\begin{tabular}{lcccc}
\hline Treatments & $\begin{array}{c}\text { Cobs plant } \\
(\mathbf{N o .})\end{array}$ & $\begin{array}{c}\text { Cob length } \\
(\mathbf{c m})\end{array}$ & $\begin{array}{c}\text { Cob diameter } \\
(\mathbf{c m})\end{array}$ & $\begin{array}{c}\text { Fresh weight } \\
\left(\mathbf{g ~ c o b}^{\mathbf{1}}\right)\end{array}$ \\
\hline Nitrogen dose $(N)$ & & & & \\
$\mathrm{N}_{1}$ & 2.11 & 8.28 & 4.16 & 31.87 \\
$\mathrm{~N}_{2}$ & 2.38 & 9.28 & 4.15 & 38.97 \\
$\mathrm{~N}_{3}$ & 2.37 & 8.81 & 4.02 & 38.01 \\
$\mathrm{~N}_{4}$ & 2.50 & 9.26 & 4.17 & 45.73 \\
\hline $\mathrm{LSD}_{(0.05)}$ & 0.36 & $\mathrm{NS}$ & $\mathrm{NS}$ & 5.69 \\
\hline
\end{tabular}




\begin{tabular}{lcccc}
\hline $\begin{array}{l}\text { Nitrogen fertilizer application } \\
\text { method }(M)\end{array}$ & & & & \\
$\mathrm{M}_{1}$ & 2.34 & 9.02 & 4.11 & 43.24 \\
$\mathrm{M}_{2}$ & 2.32 & 8.89 & 4.13 & 36.63 \\
$\mathrm{M}_{3}$ & 2.39 & 8.82 & 4.14 & 36.07 \\
\hline $\mathrm{LSD}_{(0.05)}$ & $\mathrm{NS}$ & $\mathrm{NS}$ & $\mathrm{NS}$ & $\mathrm{NS}$ \\
\hline Interactions $(N x M)$ & & & & \\
$\mathrm{N}_{1} \mathrm{M}_{1}$ & 1.91 & 8.11 & 4.06 & 30.53 \\
$\mathrm{~N}_{1} \mathrm{M}_{2}$ & 2.15 & 8.53 & 4.16 & 32.02 \\
$\mathrm{~N}_{1} \mathrm{M}_{3}$ & 2.26 & 8.19 & 4.27 & 33.07 \\
$\mathrm{~N}_{2} \mathrm{M}_{1}$ & 2.33 & 9.75 & 4.16 & 43.00 \\
$\mathrm{~N}_{2} \mathrm{M}_{2}$ & 2.26 & 9.04 & 4.14 & 38.56 \\
$\mathrm{~N}_{2} \mathrm{M}_{3}$ & 2.57 & 9.06 & 4.14 & 35.34 \\
$\mathrm{~N}_{3} \mathrm{M}_{1}$ & 2.20 & 8.27 & 3.87 & 38.37 \\
$\mathrm{~N}_{3} \mathrm{M}_{2}$ & 2.55 & 9.07 & 4.13 & 37.10 \\
$\mathrm{~N}_{3} \mathrm{M}_{3}$ & 2.36 & 9.10 & 4.05 & 38.56 \\
$\mathrm{~N}_{4} \mathrm{M}_{1}$ & 2.91 & 9.94 & 4.33 & 61.05 \\
$\mathrm{~N}_{4} \mathrm{M}_{2}$ & 2.34 & 8.94 & 4.07 & 38.84 \\
$\mathrm{~N}_{4} \mathrm{M}_{3}$ & 2.39 & 8.92 & 4.11 & 37.31 \\
\hline $\mathrm{LSD}_{(0.05)}$ & 0.360 & 1.68 & 0.51 & 9.29 \\
\hline $\mathrm{CV}_{(\%)}$ & 19.40 & 8.85 & 12.19 & 18.93 \\
\hline
\end{tabular}

$\mathrm{N}_{1}=$ No nitrogen, $\mathrm{N}_{2}=100 \mathrm{~kg} \mathrm{Nha}^{-1}, \mathrm{~N}_{3}=150 \mathrm{~kg} \mathrm{Nha}^{-1}, \mathrm{~N}_{4}=200 \mathrm{~kg} \mathrm{Nha}^{-1}, \mathrm{M}_{1}=\mathrm{Basal}, \mathrm{M}_{2}=30 \mathrm{DAS}$, $\mathrm{M}_{3}=50 \%$ basal $+50 \%$ at 30 DAS

\section{De-husked cob fresh weight}

Different nitrogen doses, application method and their interactions resulted significant variation for dehusked cob fresh weight. Higher $\mathrm{t}$ cob weight $(9.59 \mathrm{~g})$ was found in application of $200 \mathrm{~kg} \mathrm{Nha}^{-1}$ treatment $\left(\mathrm{N}_{4}\right)$ that similar to $\mathrm{N}_{2}(8.96 \mathrm{~g})$ and $\mathrm{N}_{3}(8.68 \mathrm{~g})$ and the lowest cob fresh weight $(7.95 \mathrm{~g})$ incontrol treatment (Table3). The fresh weight of dehusked cob at $200 \mathrm{~kg} \mathrm{~N}^{-1}$ was $20.63 \%$ higher compared to that of no nitrogen application treatment. Parodhanet al. (2007)also reported that highest husked, de-huskedand standard yield of baby corn was obtained with $175 \mathrm{~kg} \mathrm{Nha}^{-1}$ and it was at par with $125 \mathrm{~kg} \mathrm{~N} \mathrm{ha}^{-1}$. Similarly, Dadarwaletal. (2009) reported that increasing the rates of NPK applicationfrom 120: 40: 30 to 180: 60: $45 \mathrm{~kg} \mathrm{NPK} \mathrm{ha}^{-1}$ significantlyincreased de-husked cob and green fodder yield of baby corn. The highest cob fresh weight $(9.46 \mathrm{~g})$ was found in basal application of nitrogen fertilizer $\left(\mathrm{M}_{1}\right)$ that similar to $\mathrm{M}_{2}$ and the lowest cob fresh weight $(8.10 \mathrm{~g})$ in $\mathrm{M}_{3}$ treatment.The highest cob fresh weight (11.74 g) was found in $\mathrm{N}_{4} \mathrm{M}_{1}$ and the lowest cob fresh weight $(7.38 \mathrm{~g})$ in $\mathrm{N}_{1} \mathrm{M}_{1}$ that similar to almost all other interactions except $\mathrm{N}_{4} \mathrm{M}_{1}$ and $\mathrm{N}_{2} \mathrm{M}_{1}$.

\section{Husk fresh weight cob $^{-1}$}

Different nitrogen doses, fertilizer application method and their interactions resulted significant variation for husk fresh weight $\mathrm{cob}^{-1}$ of baby corn. The maximum $\mathrm{t}$ husk weight $(36.15 \mathrm{~g})$ was found in application of $200 \mathrm{~kg} \mathrm{Nha}^{-1}\left(\mathrm{~N}_{4}\right)$ that similar to $\mathrm{N}_{2}(30.01 \mathrm{~g})$ and the lowest husk weight $(23.69 \mathrm{~g})$ incontrol treatment (Table 3) that similar to all other treatments except $\mathrm{N}_{4}$. Higher green cob as well as green fodder yields at higher level of nitrogen was also reported by Bindhaniet al. (2007). The highest husk fresh weight $(33.60 \mathrm{~g})$ was found in basal application of nitrogen fertilizer $\left(\mathrm{M}_{1}\right)$ that similar to $\mathrm{M}_{3}$ and the lowest husk fresh weight $(27.81 \mathrm{~g})$ in $\mathbf{M}_{2}$ treatment. The highest husk fresh weight $(49.30 \mathrm{~g}$ $\mathrm{cob}^{-1}$ ) was found in $\mathrm{N}_{4} \mathrm{M}_{1}$ that differed from all other interactions and the lowest husk fresh weight (22.44 g) in $\mathrm{N}_{1} \mathrm{M}_{1}$ that similar to almost all other interactions except $\mathrm{N}_{4} \mathrm{M}_{1}$.

\section{Harvested cobs ha-1}


Different nitrogen doses as well as interactions of nitrogen dose and application method resulted significant variation for harvested cobs ha- ${ }^{-1}$. The highest number of cobs ha $\mathrm{h}^{-1}$ (196524) was found in application of $100 \mathrm{~kg} \mathrm{Nha}^{-1}$ treatment $\left(\mathrm{N}_{2}\right)$ that similar to $\mathrm{N}_{4}(193808)$ and $\mathrm{N}_{3}(182451)$ and the lowest number of cobs ha-1 (172082) in $\mathrm{N}_{1}$ (control) treatment (Table 3).

Table 3. Interaction effect of nitrogen dose and application method on yield and other crop characters of baby corn

\begin{tabular}{|c|c|c|c|c|}
\hline Treatments & $\begin{array}{c}\text { De-huskedcob } \\
\text { fresh weight } \\
\left(\mathrm{g} \mathrm{cob}^{-1}\right)\end{array}$ & $\begin{array}{c}\text { Husk fresh } \\
\text { weight } \\
\left(\text { g cob }^{-1}\right) \\
\end{array}$ & $\begin{array}{l}\text { Harvested cobs } \\
\quad(\text { no. ha' }\end{array}$ & $\begin{array}{c}\text { Cob fresh } \\
\text { yield } \\
\left(\mathrm{kg} \mathrm{ha}^{-1}\right) \\
\end{array}$ \\
\hline \multicolumn{5}{|l|}{ Nitrogen dose $(N)$} \\
\hline $\mathrm{N}_{1}$ & 7.95 & 23.69 & 172082 & 6924.71 \\
\hline $\mathrm{N}_{2}$ & 8.96 & 30.01 & 196524 & 7315.21 \\
\hline $\mathrm{N}_{3}$ & 8.68 & 29.33 & 182451 & 7265.40 \\
\hline $\mathrm{N}_{4}$ & 9.59 & 36.15 & 193808 & 7016.40 \\
\hline $\operatorname{LSD}_{(0.05)}$ & 1.623 & 6.548 & 17432.35 & NS \\
\hline \multicolumn{5}{|c|}{$\begin{array}{l}\text { Nitrogen fertilizer application } \\
\operatorname{method}(M)\end{array}$} \\
\hline $\mathrm{M}_{1}$ & 9.46 & 33.60 & 179797 & 6742.74 \\
\hline $\mathrm{M}_{2}$ & 8.82 & 27.81 & 188870 & 7431.16 \\
\hline $\mathrm{M}_{3}$ & 8.10 & 27.97 & 189981 & 7217.39 \\
\hline $\operatorname{LSD}_{(0.05)}$ & 0.99 & 5.75 & NS & NS \\
\hline \multicolumn{5}{|l|}{ Interactions $(N \times M)$} \\
\hline $\mathrm{N}_{1} \mathrm{M}_{1}$ & 7.38 & 22.44 & 157021 & 6135.83 \\
\hline $\mathrm{N}_{1} \mathrm{M}_{2}$ & 8.53 & 23.49 & 175538 & 7104.10 \\
\hline $\mathrm{N}_{1} \mathrm{M}_{3}$ & 7.94 & 25.13 & 183685 & 7504.34 \\
\hline $\mathrm{N}_{2} \mathrm{M}_{1}$ & 9.69 & 33.31 & 187389 & 7219.22 \\
\hline $\mathrm{N}_{2} \mathrm{M}_{2}$ & 8.55 & 30.01 & 183685 & 7408.14 \\
\hline $\mathrm{N}_{2} \mathrm{M}_{3}$ & 8.64 & 26.70 & 218497 & 7318.26 \\
\hline $\mathrm{N}_{3} \mathrm{M}_{1}$ & 9.01 & 29.35 & 162947 & 7450.25 \\
\hline $\mathrm{N}_{3} \mathrm{M}_{2}$ & 8.89 & 28.20 & 203683 & 7479.97 \\
\hline $\mathrm{N}_{3} \mathrm{M}_{3}$ & 8.13 & 30.43 & 180723 & 6865.98 \\
\hline $\mathrm{N}_{4} \mathrm{M}_{1}$ & 11.74 & 49.30 & 211831 & 6165.68 \\
\hline $\mathrm{N}_{4} \mathrm{M}_{2}$ & 9.32 & 29.52 & 192573 & 7732.41 \\
\hline $\mathrm{N}_{4} \mathrm{M}_{3}$ & 7.69 & 29.61 & 177019 & 7180.96 \\
\hline $\operatorname{LSD}_{(0.05)}$ & 1.97 & 11.49 & 36962.60 & 1527.68 \\
\hline CV (\%) & 12.97 & 22.29 & 11.47 & 12.38 \\
\hline
\end{tabular}

$\mathrm{N}_{1}=$ No nitrogen, $\mathrm{N}_{2}=100 \mathrm{~kg} \mathrm{Nha}^{-1}, \mathrm{~N}_{3}=150 \mathrm{~kg} \mathrm{Nha}^{-1}, \mathrm{~N}_{4}=200 \mathrm{~kg} \mathrm{Nha}^{-1}, \mathrm{M}_{1}=$ Basal, $\mathrm{M}_{2}=30 \mathrm{DAS}, \mathrm{M}_{3}=50 \%$ basal $+50 \%$ at $30 \mathrm{DAS}$

Higher green cob as well as green fodder yields at higher level of nitrogen was also reported by Bindhaniet al. (2007). The highest number of cobs ha ${ }^{-1}$ (218497) was found in $\mathrm{N}_{2} \mathrm{M}_{3}$ that similar to $\mathrm{N}_{4} \mathrm{M}_{1}$ (211831), $\mathrm{N}_{3} \mathrm{M}_{2}$ (203683), $\mathrm{N}_{4} \mathrm{M}_{2}$ (192573), $\mathrm{N}_{2} \mathrm{M}_{1}$ (187389), $\mathrm{N}_{2} \mathrm{M}_{2}$ (183685) and $\mathrm{N}_{1} \mathrm{M}_{3}$ (183685). The lowest number of cobs ha ${ }^{-1}$ (157021) found in $\mathrm{N}_{1} \mathrm{M}_{1}$ that similar to almost all other interactions except $\mathrm{N}_{2} \mathrm{M}_{3}, \mathrm{~N}_{3} \mathrm{M}_{2}$ and $\mathrm{N}_{4} \mathrm{M}_{1}$.

\section{Fresh cob yield}

Different nitrogen doses and application method showed non-significant variation for fresh cob yield $\mathrm{ha}^{-1}$ of baby corn but their interactions was found significant. The highest cob yield ha $\mathrm{h}^{-1}(7732.41 \mathrm{~kg})$ was found in $\mathrm{N}_{4} \mathrm{M}_{2}$ that similar to all other interactions except $\mathrm{N}_{1} \mathrm{M}_{1}$ and $\mathrm{N}_{4} \mathrm{M}_{1}$ andthe lowest fresh cob yield ha ${ }^{-1}(6135.83 \mathrm{~kg})$ found in interaction of $\mathrm{N}_{1} \mathrm{M}_{1}$ that similar to all other interactions except $\mathrm{N}_{4} \mathrm{M}_{2}$.

\section{Conclusion}


Based on the results of the study it may be concluded that baby corn can be successfully cultivate in Bangladesh. Increment of nitrogen dose increased the fresh cob weight of baby corn but the number remain unchanged. Nitrogen fertilizer application method had no remarkable impact on cob yield. Application of $200 \mathrm{~kg} \mathrm{~N} \mathrm{ha}^{-1}$ as basal dose or $150 \mathrm{~kg} \mathrm{~N}$ ha $^{-1}$ having $50 \%$ as basal dose and rest $50 \%$ as side dressing at 30 days after sowing might be recommended for baby corn cultivation. However, to reach a specific conclusion and recommendation experiments with different levels of other fertilizers and with more varieties should be repeated in different Agro-ecological zones.

\section{Acknowledgement}

The author acknowledged the Ministry of Science and Technology, Govt. of the People's Republic of Bangladesh for providing financial support to conduct the study.

\section{References}

Ashok Kumar. 2008. Productivity, economics and nitrogen- use efficiency of specialty corn (Zea mays) as influenced by planting density and nitrogen fertilization. Indian J. Agron. 53(4): 306-309.

Ahmed, F. 1994. Maize Production Technology (in Bengali). International Fertilizer Development Center (IFDC) - consultant of Ministry of Agriculture, Bangladesh.

Bakshi, M.P.S. and M. Wadhwa. 2012. Nutritional evaluation of baby corn husk-A new feed resource for livestock. Indian J. Anim. Sci. 82: 1548-50.

Bakshi, M.P.S., M. Wadhwa and H.P.S. Makkar. 2016. Wastes to worth: vegetable wastes and by-products as animal feed. Commonwealth Agric. Bureau Rev. 11: No. 012.

BARI (Bangladesh Agriculture Research Institute). 2004. Production Technology of Baby corn(In Bengali). Agronomy Division, BARI, Joydebpur, Bangladesh.

Bindhani, A., K.C. Barik, L.M. Garnayak and P.K. Mahapatra. 2007. Nitrogen management in baby corn (Zea mays L.). Indian. J. Agron. 52: 135-138.

Bar-Zur, A. and H. Saadi. 1990. Prolific maize hybrids for corn. J. Hort. Sci.65: 97-100.

Dadarwal, R.S., N.K. Jain and D. Singh. 2009. Integrated nutrientmanagementin baby corn (Zea mays). Indian J. Agric. Sci.79(12): 1023-1025.

Das, S., V.K. Yadav, Jat, K. Asha, R. Sujay, K. Joyti and J.C. Sekhar. 2008. Babycorn in India. DMT Technical Bulletin. Directorate of Maize Research, Pusa campus, New Delhi: 1-45.

Ghosh, M., S.K. Maity, S.K. Gupta and A.R. Chowdhury. 2017. Performance of baby corn under different plant densities and fertility levels in lateritic soils of eastern India, Int. J. Pure App. Biosci. 5(3):696-702. doi: http://dx.doi.org/10.18782/2320-7051.5012.

Kar, P.P., K.C. Barik, P.K. Mahapatra, L.M. Garnayak, B.S. Rath, D.K. Bastia and C.M. Khanda. 2006. Effect of planting geometry and nitrogen on yield, economics and nitrogen uptake of sweet corn (Zea mays). Indian J. Agron. 51(1): 43-45.

Muniswamy, S., R.Gowda and S.R. Prasad. 2007. Effect of spacing and nitrogen levels on seed yield and quality of maize single cross hybrid PEHM-2. Mysore J. Agric. Sci. 41(2): 186-190.

Nielsen, R.B. 2013. Root Development in Young Corn, In: Purdue University Department of Agronomy.

Pandey, A.K., V.P. Moni, V. Prakash, R.D.Singh and H.S. Gupta. 2002. Effect of varieties and plant densities on yield, yield attributes and economics of baby corn (Zea mays). Indian J. Agron. 47: 221-226.

Parodhan, R.S., S. Bala and P. Khoyumthem. 2007. Response torate of nitrogen and effect of rate of nitrogen and effect of plant density on yield of baby corn. J. Intercad. 11(3): 265-269.

Prathyusha, C. and S. Hemalatha. 2013. Yield and economics of specialty corn at various levels of nitrogen application under Pongamia + Maize Agri-Silvy system. Intl. J. Adv. Res. 1(6): 476-481. 
Ramchandrappa, B.K., I.I.V. Nangappa and I.I.K. Shiva Kumar. 2004. Yield and quality of babycorn (Zea mays L.) as influenced by spacing and fertilizer levels. Acta Agron.Hungarica. 52: 237-243. http://dx.doi.org/10.1556/AAgr.52.2004.3.4.

Sahoo, S.C. and P.K. Mahapatra. 2004. Response of sweet corn (Zea mays) to nitrogen levels and plant population. Indian J. Agric. Sci. 74(6): 337-338.

Salahuddin, M. and N.A. Ivy. 2003. Cultivation of Maize. Production and uses of maize in Bangladesh. pp.29-35.

Singh, N.B. and P.P. Singh. 1984. Effect of intercropping with legumes on grain yield of maize and its residual effect on succeeding wheat. Indian J. Agron. 29: 295-298.

Suryavanshi, V.P., B.N. Chavan, K.T. Jadhav and P.A. Pagar. 2008. Effect of spacing, nitrogen and phosphorous levels on growth, yield and economics of Kharif maize. Intl. J. Trop. Agric. 26(3- 4): 287-291.

Thakur, D.R., O. Prasad, P.C.Kharwara and S.K. Bhalla. 1997. Effect of nitrogen and plant spacing on growth, development and yield of baby corn. Indian J. Agron. 42(3): 479-483.

Thakur, D.R., V. Sharma and S.R. Pathik. 2000. Evaluation of maize (Zea maysL) cultivars for their suitability baby corn under mid-hills of north-western Himalayan. India J. Agril. Sci. 70: 146-148. 